DIW BERLIN

Discussion

Papers

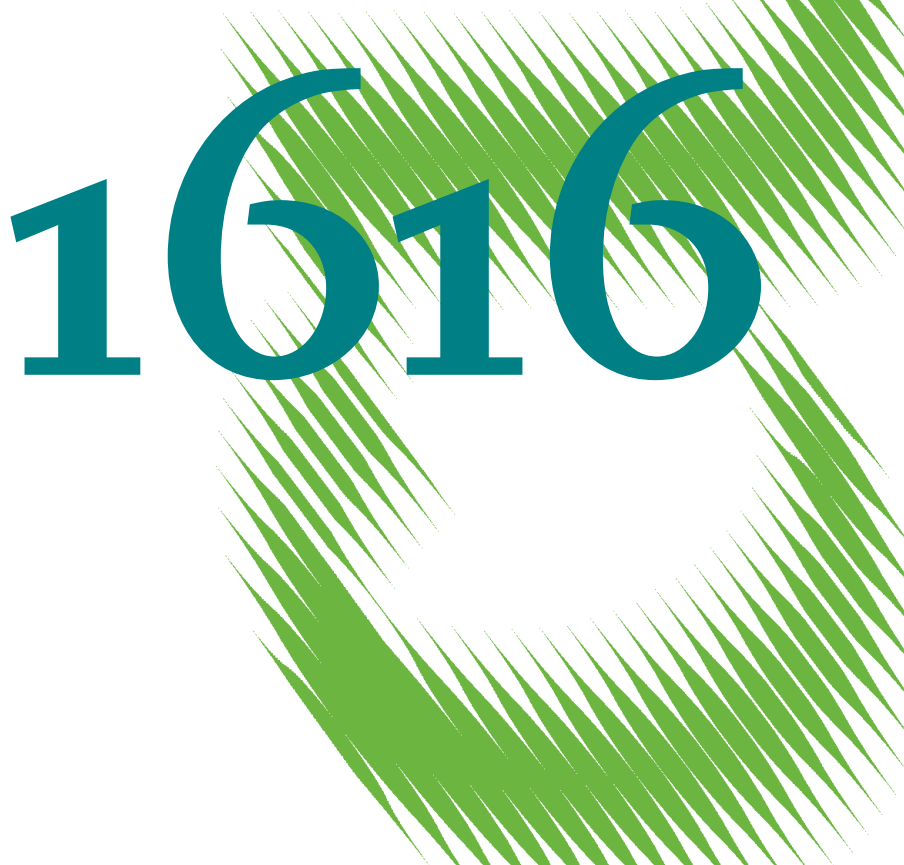

The Impact of Lengthening the School Day on

Substance Abuse and Crime

Evidence from a German High School Reform 
Opinions expressed in this paper are those of the author(s) and do not necessarily reflect views of the institute.

IMPRESSUM

(C) DIW Berlin, 2016

DIW Berlin

German Institute for Economic Research

Mohrenstr. 58

10117 Berlin

Tel. +49 (30) $89789-0$

Fax +49 (30) $89789-200$

http://www.diw.de

ISSN electronic edition 1619-4535

Papers can be downloaded free of charge from the DIW Berlin website:

http://www.diw.de/discussionpapers

Discussion Papers of DIW Berlin are indexed in RePEc and SSRN:

http://ideas.repec.org/s/diw/diwwpp.html

http://www.ssrn.com/link/DIW-Berlin-German-Inst-Econ-Res.html 


\title{
The impact of lengthening the school day on substance abuse and crime: Evidence from a German high school reform
}

\author{
Franz G. Westermaier*
}

October 2016

\begin{abstract}
In the 2000s, a major educational reform in Germany reduced the academic high school duration by one year while keeping constant the total number of instructional hours before graduation. The instructional hours from the eliminated school year shifted to lower grade levels, which increased the time younger students spend at school. This study explores the impact of the reform on youth crime rates and substance abuse using administrative police crime statistics, administrative student enrollment data, and a student drug survey.

The staggered implementation of the reform in different Länder-age-groups allows for a difference-in-difference approach. I find that the reform resulted in a decline in crime rates, which is almost exclusively driven by a reduction in violent crime and illegal substance abuse. Regarding the latter, the rate of illegal cannabis consumption strongly declined; however, no significant effect is detected on cannabis dealers or the consumption of other illegal drugs. The survey evidence further suggests that decreased cannabis consumption was not driven by a shift of consumption into 'school hours'. The results point to an 'incapacitation' effect of schooling due to the increased instructional hours at lower grade levels.
\end{abstract}

JEL-Classification: I12, I28

Keywords: illegal substance abuse, school reform, difference-in-difference

Acknowledgments : I thank Peter Haan, Annika Herr, Klaus Hurrelmann, Stephen Machin and Christian Traxler for valuable comments. Furthermore, I want to thank Olivier Marie for sharing the crime data and Theo Baumgärtner for providing access to the student drug survey.

* DIW Berlin, Mohrenstraße 58, 10117 Berlin f.westermaier@alumni.hertie-school.org 



\section{Introduction}

Cannabis is the most consumed illegal drug in Germany and ranks third after the legal substances of alcohol and nicotine 1 Furthermore, cannabis is the most prominent illegal drug among the youth in Germany and is considered responsible for two-thirds of drugrelated crimes among youth. Regardless of efforts to decriminalize the consumption of cannabis, it is an undisputed aim to prevent children and adolescents from consuming any type of drug. To educate students about drugs and their risks, the school curriculum includes lessons on substance abuse prevention and is supported by anti-drug campaigns in Germany.

This study analyzes the effect of lengthening the academic high school track school day on illegal substance abuse and criminal behavior. Following Germany's school reform, the final year of high school was eliminated with the instructional hours shifted to lower grades. This increase in school hours reduces opportunities for students to obtain and consume drugs. I estimate the impact of an increase in instructional hours on the crime rates of the age groups affected by the reform. Affected students receive the same total number of instructional hours prior to graduation, which forces them to spend more time at school in lower grade levels. This shift mainly affected the middle grades of the high school period, whereas an increase in instructional hours during the last years before graduation was moderate, because of an already dense curriculum at these grade levels.

The link between education and crime is extensively studied (Ehrlich, 1975; Jacob and Lefgren, 2003; Lochner and Moretti, 2004). Most studies in this area rely on exogenous variation via reforms in the institutional framework to assess the impact of education on high-risk youth groups with respect to crime. The economic literature distinguishes between two channels through which education can impact crime. The first channel works through an investment in education, which increases the opportunity costs of committing crimes. The second channel works through incapacitation in school and can be explained by the fact that the time spent at school cannot be used to commit crimes. This incapacitation effect does not necessarily depend on the quality of education. Kline (2012) finds that simple curfews, as a form of incapacitation, are effective at reducing both violent and property crimes by juveniles.

This study differs from previous literature in that I can estimate the effect of schooling on crimes committed by high-performing students who should be a relatively low-risk

\footnotetext{
${ }^{1}$ See Drogenbeauftragte (2013) for an overview of drug consumption in Germany. Alcohol spirits and nicotine are forbidden to adolescents younger than 18. Beer and wine are prohibited for those less than 16.
} 
youth group with respect to delinquent behavior. Students in an academic high school track intend to pursue a school career beyond the minimum dropout age and, thus, are not affected by changes to it.

To estimate the causal impact of the high school reform on crime rates, the underlying analysis applies a difference-in-difference strategy, which uses variation over time between the Länder (German Federal States) and the affected age groups 2 The results suggest that the increase in instructional hours at lower grades slightly decreases overall crime rates of the affected age groups. However, the drop in crime rates is mostly driven by declining violent and drug-related crimes. Furthermore, in-depth analysis reveals that fewer cannabis users in affected age groups are being arrested, while the arrest rates of cannabis dealers seems not to be affected.

A common approach to study the exogenous effects of education on crime is to monitor changes in the minimum dropout age (cf. Anderson 2014, Machin et al. 2011, and Brilli and Tonello 2015). This identification strategy ensures that potential offenders are affected by the reform because early school dropouts show higher offender rates than classmates who remain at school. Given that these students have lower opportunity costs in education than high-performing students, one can suspect a stronger effect of education on crime for low-performing students. However, to the best of my knowledge, the evidence of the educational effect on crime for high-performing students who are hardly affected by minimum dropout age regulations is scarce, especially with regard to drug-related crimes.

Jacob and Lefgren (2003) present evidence on the contemporaneous effect of schooling on crime in the US using in-service days of teachers as a source of exogenous variation ${ }^{3}$ Their results suggest that students who are incapacitated at school have relatively fewer possibilities to prepare for or commit criminal activities, at least in the case of property crime. However, incapacitation of students in school increases violent criminal behavior in the US. Similar evidence is provided by Luallen (2006) who explores the effect of teacher strike days (reduced classroom teaching time) on criminal activities. These measured incapacitation effects are, in general, comparable with the reform's effect of increased instructional hours discussed in this study; however, they cannot differentiate between specific secondary school types and their students.

Deming (2011) uses lotteries for attending first-choice schools to estimate the impact

\footnotetext{
${ }^{2}$ Please see Chevalier and Marie (2016) for a description of the research method and Chevalier and Marie (2013) for another application of the crime data.

${ }^{3}$ Teachers deal with administrative duties on these in-service days, while students do not have to attend school. Jacob and Lefgren (2003) show that these in-service days are more exogenous than weekends or national holidays.
} 
of education on crime rates seven years after graduation. He shows that 'winning' students benefit from a higher school quality through better qualified teachers and from less crime prone peer groups. Furthermore, he finds that 'winning' students have lower crime and incarceration rates during and after their school careers. He notes that especially in the age group of middle-school children, the peer group effect has a strong negative influence on violent crime. However, he admits that the 'winning' students are drawn from a population with a low social and economic background. These results are in line with Becker (1968) and can be explained by the increased opportunity costs of crime due to potentially higher earnings in the legitimate sector.

Åslund et al. (2015) study the effect of education on crime with a Swedish reform of the vocational upper secondary education, extending the curriculum from two to three years. This reform targets students who are a high-risk group with respect to criminal behavior. They find a negative effect of the additional school year on property crime but not on violent crime, which can also be explained by an incapacitation effect. In comparison to this study, which focuses on high-performing students, the underlying reform of their study affected mostly low-performing students. Berthelon and Kruger's (2011) study relates most closely to the present research. They use a school reform in Chile that lengthened the school day for public and publicly funded private schools. The lengthened school day was found to not just reduce the likelihood of teenage pregnancy but it also decrease juvenile property and violent crimes.

To my knowledge, the current study is the first to examine the impact of an educational reform focusing on substance abuse. The staggered implementation of the reform over different Länder, grade levels, and years serves as a source of the exogenous variation of schooling via instructional hours. The design of the reform allows for an evaluation approach that explores differences over time, age cohorts, and between Länder.

The present study also provides evidence from a regional student drug survey taken in the Land of Hamburg, which supports the findings from the police crime data. It shows that the reduction of cannabis users after the reform was driven by a decreasing consumption by the reform-affected students and rejects the hypothesis of drug consumption shifting into school hours.

The remainder of the paper is organized as follows. Section 2 provides a literature review and the institutional framework. Section 3 describes the datasets. Section 4 explains the identification and estimation strategy. Section 5 presents the results and Section 6 concludes the study. 


\section{Literature Review and Institutional Framework}

\section{$2.1 \quad$ Literature Review}

Several studies use the German high school reform implementation to evaluate the impact of the eliminated school year on educational achievements and other outcomes 4 Huebener and Marcus (2014) find that the main goal of the reform, reducing graduation age, was achieved. But, the rate of grade repetition shortly before graduation doubled after the reform. It is not clear whether the increase in grade repetition rates is a long-term effect or is driven by frictions during the implementation process. Büttner and Thomsen (2015) find negative effects of the reform on grades in math in one Land. A similar reform occurred in the U.S., which reduced the days per week that students spend in school. Anderson and Walker (2015) analyze the effect of a shift from a five- to four-day school week on student achievement in rural areas. To ensure the minimum state-mandated requirements, these schools needed to increase instructional hours per day. Anderson and Walker find positive, rather than negative, effects of the lengthened school day on math and reading test scores.

Dahmann and Anger (2014) discover that after the German high school reform students are slightly more extroverted and less emotionally stable than those from nonreformed high schools. A psychological survey by Milde-Busch et al. (2010) does not find any difference in headache and other stress measures after the reform, but results do show that students with a lengthened school day declare fewer hours of spare time.

\subsection{German Education System}

Education policy is not centralized in Germany, but it is one of the main responsibilities of each German Land, and federal responsibilities are limited. Länder can reform their education systems independently. However, a voluntary assembly of Länder ministers of education coordinates reforms and ensures a comparable set of standards.

In Germany, students begin primary schooling close to their $6^{\text {th }}$ birthday at enrollment. Given this average age of students within primary school, students are, roughly, 10 years old when tracking occurs in secondary school (high school).$^{5}$ Based on students' competences and preferences, teachers or parents decide which track the students should

\footnotetext{
${ }^{4}$ Cf. Kühn et al. 2013, Meyer et al. (2015).

${ }^{5}$ Three out of sixteen Länder track their students after the $6^{\text {th }}$ grade. Furthermore, some schools offer a curriculum for up to three tracks within one school institution.
} 
attend in their secondary school education ${ }^{6}$

The 'Gymnasium' is the highest academically focused secondary school track and covers grades 5 to 12 (i.e., 5 to 13 before the reform) 7 Graduates from these schools receive a general qualification of university entrance and can study at a university or polytechnic tertiary teaching institution without any further training.

The 'Realschule' track offers a less academic curriculum for secondary school covering grades (5-10), and prepares students for an apprenticeship, typically leading to white-collar jobs. The 'Hauptschule' track has the least academic curriculum, ending after grade 9, and prepares students for an apprenticeship that will lead to trade or the industrial sector. However, the tracking between Realschule and Hauptschule is less welldefined in some Länder, due to comprehensive schools with a curriculum that is more independent from the track. 8

The Gymnasium track covers the largest group of students in most Länder and was exclusively subject to the high school reform. Similar vocational grammar schools with an equivalent university entrance diploma kept the old curriculum? The 2001 Gymnasium track accommodates approximately $30 \%$ of a student's age cohort. However, this share has increased over the last 10 years, to approximately $40 \%$ of a student's age cohort in 201210

\section{$2.3 \quad$ G8 Reform}

The object of the reform, which eliminated the last high school year, was to support students with an earlier entry into the university (or job market) in accordance with international education systems. Hence, the years of secondary education in the Gymnasium decreased from nine years $(G 9)$ to eight years $(G 8){ }^{11}$

After the reform, the total number of instructional hours remained constant, but the

\footnotetext{
${ }^{6}$ Whether parents or teachers decide the optimal secondary school type depends on the legal framework in each Land. For a detailed description of tracking in Germany, see Dustmann (2004).

${ }^{7}$ Students who start their secondary school period at other school types can switch to a Gymnasium generally on the completion of each school year if their academic performance is high, however, students usually switch tracks after finishing their current school and attend a Gymnasium at corresponding later levels.

${ }^{8}$ Beyond the traditional three-track system, Germany offers comprehensive schools Gesamtschulen and special schools for children who are physically or mentally challenged (Förderschulen).

${ }^{9}$ Students in vocational grammar schools can receive university entrance qualification even after graduation; however, the high school phase of vocational schools remained until the $13^{\text {th }}$ grade and was not affected by the reform.

${ }^{10}$ Based on the Annual Report of general education from the Federal Statistical Office of Germany, 2001-2012.

${ }^{11} G 9$ refers to the old school regime and $G 8$ refers to the new reformed school regime.
} 
length of the school day increased at the lower grade levels ${ }^{12}$ However, the workload at the first two grades in the Gymnasium (grades 5 and 6) was not substantively increased in order to avoid increasing the burden during the transition from primary to secondary school. ${ }^{13}$ Finally, the already high number of instructional hours at the final stage of the Gymnasium (grades 11 and 12) prevent any additional increase of instructional hours directly before graduation. As a result, the 'shifted' instructional hours of the old $13^{\text {th }}$ grade were mainly distributed across grades 7 to 10, which increased the instructional hours per day by up to $20 \%$. Many schools switched from a half-day to a full-day program to deal with the reform.

The implementation of the G8 reform was staggered over the Länder and with different grade levels affected first. Table 1 provides an overview of the implementation in the German Länder. Two East German Länder, Saxony and Thuringia, had not changed high school length after reunification and were already operating under the 68 policy. However, the other East German Länder adopted the West German G9 regime following reunification in 1990. The first West German Land to introduce the shorter high school system was Saarland, altering the $5^{\text {th }}$ grade in the $2001 / 2002$ school year. The first graduates of this reform finished school in the double G8 and G9 graduation year, 2009. However, Saxony-Anhalt was the first Land with a double graduation cohort in 2007. As the G8 reform in the $2003 / 2004$ school year affected the $9^{\text {th }}$ grade and below, the $9^{\text {th }}$ and $10^{\text {th }}$ grades of the $2003 / 2004$ school year graduated together in $2007,{ }^{14}$

\footnotetext{
${ }^{12}$ According to the Kultusminsiterkonferenz (KMK, 2013), the average hours per week in the Gymnasium increased from 29.44 to 33.13 .

${ }^{13}$ Some Länder foster easier transitions between the different school tracks at the entrance to the secondary school phase. In the so-called 'Orientierungsstufe' or 'Förderstufe which covers the $5^{\text {th }}$ and $6^{\text {th }}$ grade, student tracking is less strict.

${ }^{14}$ For further information regarding the relative short implementation phase in Saxony-Anhalt and the impact on educational outcomes, see Büttner and Thomsen (2015).
} 


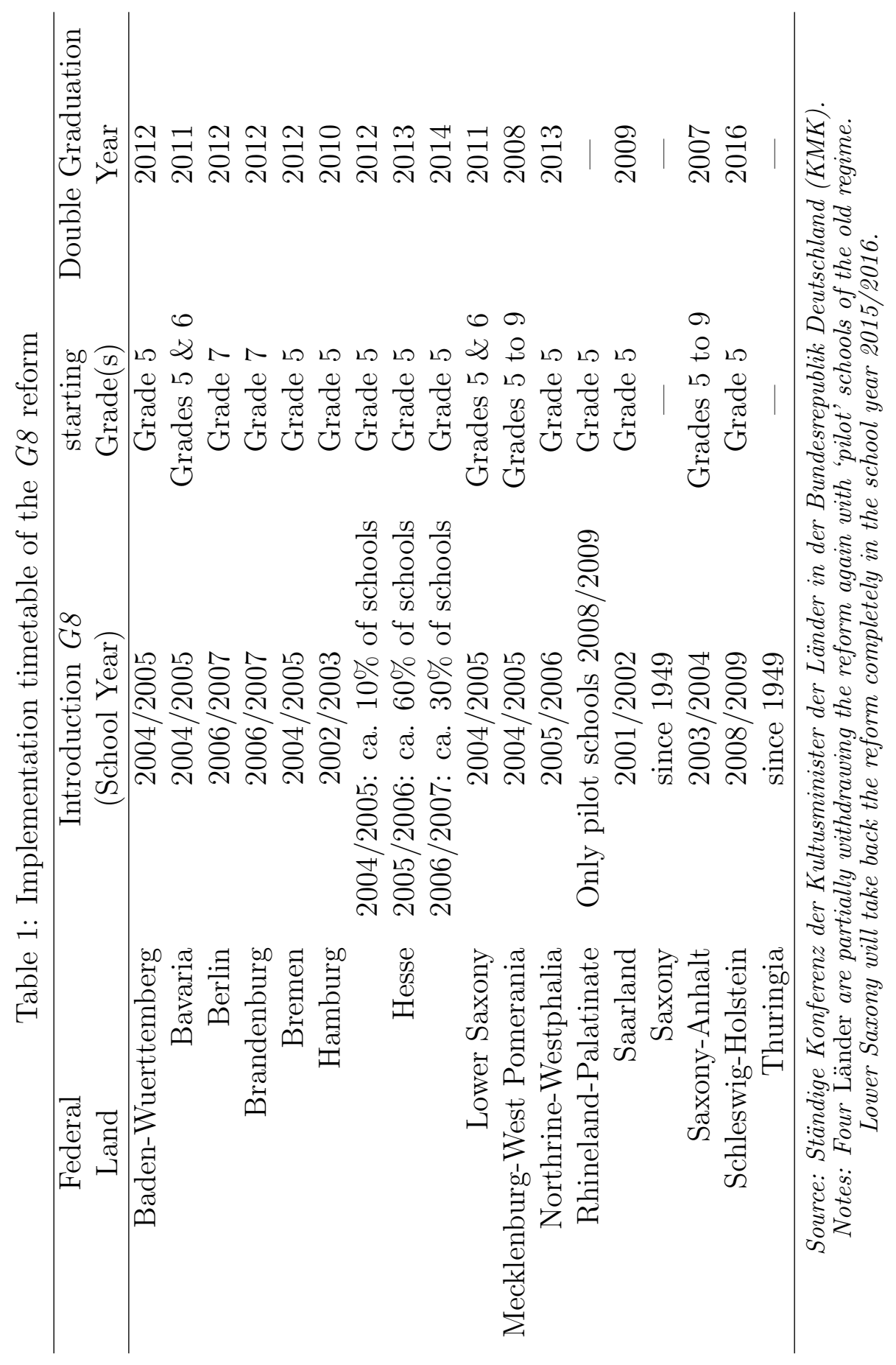


Figure 1 plots the actual share of reform affected Gymnasium students relative to all Gymnasium students across the Länder for the years 1998 to 2012 by two- and threeyear age groups. The staggered implementation starts around 2002. However, due to the Länder Saxony and Thuringia, which had the G8 regime since 1949, a small fraction of G8 Gymnasia was already present prior to 2002.

Figure 1: Relative share of students in the G8 track relative to all Gymnasium students (G8 and G9)

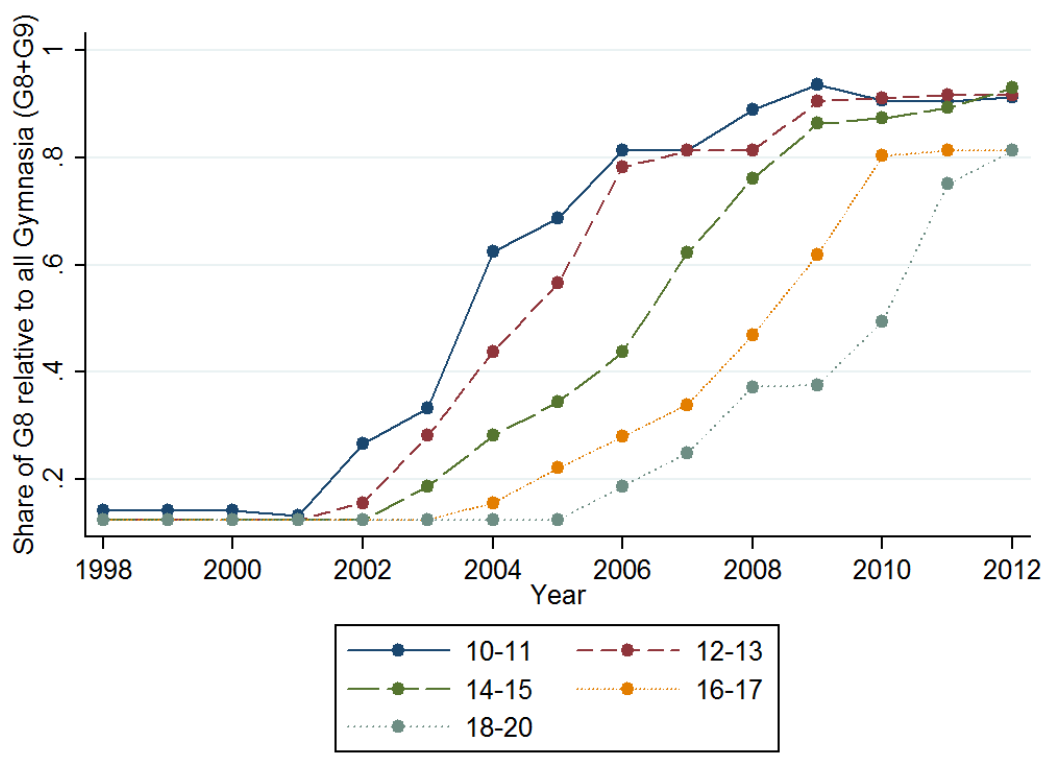

Notes: Based on administrative student data. This graph shows the shares of students in the G8-reformed track relative to all Gymnasium students (with and without reform) for specific age groups. The students share is based on the G8-reformed students in each grade level, but refers to the corresponding age groups in the respective grade levels.

Figure 1 shows that the $G 8$ reform has affected almost all Gymnasium students, with over $80 \%$ of academic high school students affected since 2011.

Since the crime data used in this analysis is mostly aggregated over two-year age cohorts, I calculate the share of G8-reformed students based on the corresponding two year grade levels. Due to this fact, it may be that only one half of a two-year age cohort was affected by the reform. Furthermore, only the 18-year-olds in the three-year age group of 18 to 20-year-olds could be affected by the reform, which reduces the maximum reform impact to one third of this three-year age cohort. To capture the maximum reform impact for further analysis, I construct a G8 reform dummy that takes the value of 1 when the Gymnasium track of a two-year age group was subject to the $G 8$ reform in a given year and Land. The G8 reform dummy takes the value of $\frac{1}{2}$ when only one age cohort out of 
the two-year age group is affected in a given year ${ }^{15}$ The dummy variable takes the value of 0 for all other (not reformed) age groups in a given year.

\subsection{Implications of the G8 Reform for Crime}

Theoretically, it is not clear whether the $G 8$ reform would increase or decrease the crimes committed by affected students. Students could exhibit higher stress measures due to an increased workload, in comparison with students receiving the standard curriculum. One way to cope with the increased stress, at least in the short run, could be escapism through increased drug consumption. Violent crimes could also increase if students act out through violent behavior or are more short-tempered and engage more frequently in physical conflicts as a result of increased stress brought on by the G8 reform. However, Milde-Busch et al. (2010) show that stress measures for reform-affected students are not significantly higher than those of high school students prior to the $G 8$ reform $\left[{ }^{16}\right.$

Alternatively, increased instructional hours leave students with less residual time for committing crimes. This form of incapacitation means that students cannot commit crimes outside the school as long as they are in school. A similar effect may occur when students invest more time in studying at home to cope with the increased curriculum content, a form of self-incapacitation 17

While it seems theoretically feasible to just shift the crime to the after-school time of day or the weekends, the $G 8$ reform reduced the residual spare time of students and therefore hampered criminal behavior through simple displacement. In general, crimes and drug consumption can also increase within the school environment simply because the lengthened school day offers more opportunities to commit crimes during school hours. ${ }^{18}$ However, this effect should be less relevant for high-performing students who have an educational aspiration and pursue an academic school track. Furthermore, teacher supervision makes committing crimes difficult in the school, including recess and small breaks within school days. I will assess this potential effect for cannabis consumption with a student drug survey in Section 5.3 .

It might be also the case that a change in student's criminal behavior is a result of the

\footnotetext{
${ }^{15}$ This can be the case in the introduction phase of the $G 8$ reform, when only the younger or lower age cohort of a two-year age group was affected. Furthermore, the $G 8$ reform dummy takes the value of $\frac{1}{3}$ to account for the reform-affected 18-year-old students in the 18-20 age cohort.

${ }^{16}$ In fact, Milde-Busch et al. (2010) find that the stress measures of Gymnasium students are high irrespective of the $G 8$ reform.

${ }^{17}$ Given the age of students, this form of self-incapacitation may even be enforced by the parents, especially for younger students.

${ }^{18}$ Luallen (2006) finds that this effect is present in the U.S. for violent crime, but not for other types of crime.
} 
changes in educational outcomes, directly altered by the reform. If the reform increased the returns to schooling for affected students, the opportunity costs of crime will increase and makes committing crime less profitable. Therefore, I cannot rule out that the total reform impact is a combination of these different channels.

\section{Data}

To study the $G 8$ reform's impact on crime, I compile various datasets that record crimes and substance abuse. To link the crime data with the G8-reformed students, I rely on yearly student enrollment data, which records the number of students in different school tracks and grades. Additionally, I gather annual information from the Federal Statistical Office to use as control variables, including the population size of an age cohort, unemployment rate, youth unemployment rate, and police expenditures.

\subsection{Police Crime Statistics (PKS)}

The police crime statistics (PKS) used in this study is administered by the federal criminal police office 19 These data allow for a comparison of crime rates among all Länder in Germany since 1993. An annual sample of the data covers all offenders, their criminal charges, gender, and corresponding age group. The recorded crime charges are based on police arrests rather than on criminal convictions, which might differ. I use these data until the most recent wave in 2012 and observe the groups with the following age cohorts (in years): 10-11, 12-13, 14-15, 16-17, 18-20, and 21-22. The population between the ages 10 and 18 can be, in general, subject to the G8 reform, whereas those aged 19 to 22 years are not and serve only for further analysis.20

The detailed description of law violations allow me to aggregate categories of violent-, property-, and drug-related crimes. Aggregated violent crimes include assaults, homicides, and robberies. Aggregated property crimes capture any forms of theft. Aggregated drug-related crimes include all possessions or trades of illegal substances and any crimes associated with obtaining drugs. The fact that the police only reports crimes where a charge occurs, and that the true crime rate is probably higher, is not a serious measurement error as long as the fraction of reported crimes with respect to the true crime rate

\footnotetext{
${ }^{19}$ Source: PKS Bundeskriminalamt, 1998-2012. Data license Germany,- attribution Version 2.0. www.bka.de/DE/Publikationen/PolizeilicheKriminalstatistik

${ }^{20}$ The age cohorts of the years 19-22 make it possible to analyze potential catch-up effects of former G8 track students after their school career.
} 
is not affected by the G8 reform. Furthermore, the police can only charge a crime in the data if the suspect is known ${ }^{21}$

\subsection{Student Enrollment Data}

To link youth crime rates with student data, I gather the student enrollment shares under the $G 8$ and $G 9$ regimes, based on the annual report of general education from the Federal Statistical Office of Germany. These data provide the number of students in each school type for each school grade in the different Länder from the 1998/99 school year through 2012/13 ${ }^{22}$ These data also allow me to capture the share of students in the old G9 regime and the new $G 8$ regime, which is necessary for linking each to age group-specific crime rates. Since it is not possible to identify the actual age of students within one grade in a given school year, I use the legal age at school start to determine the grade level of the age groups in the youth crime data.

Due to the half-year shift in the school year with respect to the calendar year, I assign half of the students in the $5^{\text {th }}$ grade as 10-year-olds and the other half as 11-year-olds. This results in a graduation age of 17 and 18 years, respectively, when students finish the G8-reformed Gymnasium following completion of the $12^{\text {th }}$ grade. This does not account for grade repetitions by affected students. Huebener and Marcus (2015) find that the repetition rates in the last three grades before graduation have increased due to the G8 reform, which could bias the results for older students. However, grade repetition is least frequent in the Gymnasium among the traditional secondary school branches. To merge the two year groups' crime data, I aggregate the students' school enrollment data. To account for potential correlation of residuals within Länder and across age cohorts, I cluster the standard errors for all models estimated with the PKS data on the Land level 23

\subsection{Schulbus Survey Data}

The Schulbus Survey, a study on substance abuse among adolescents in and around Hamburg, conducted between since 2004, covers students between the ages of 14 and 17 years. In total, the sample I use covers 2004, 2005, 2007, 2009, and 2012. The introduction of

\footnotetext{
${ }^{21}$ The overall crime clearance ratio is, on average, $55 \%$, but varies strongly with specific crimes. The drug-related and violent crime clearance ratios are over $95 \%$ and $80 \%$, respectively.

${ }^{22}$ Data are missing for the 2000/01 school year for Thuringia and Saxony-Anhalt, which I interpolate with the average number of students in the previous and following school years.

${ }^{23}$ The results for the small number of clusters due to only 16 federal Länder are confirmed by regressions with a wild bootstrap procedure and other cluster units (i.e., interaction of Land and birth cohort).
} 
the G8 reform in Hamburg during the 2002/03 school year with the $5^{\text {th }}$ grade ensures that I have a reasonable number of older Gymnasium students that were not affected. All fourteen-year-old Gymnasium students up to 2005 were already too old to be affected, whereas the fourteen- and fifteen-year-old Gymnasium students in 2007 were the first ones affected by the G8 reform; from 2009 on, all Gymnasium students younger than seventeenyears-old were subject to the $G 8$ reform. The survey is a repeated cross-section sample of secondary school students and explores students' general substance abuse, whether drug experiences were gained within the school environment, and the prevalence of substance abuse within peer-groups. The original sample consists of 5,508 students in the different implementation waves. I drop the students whose place of residence is unclear (405 observations) and those students who are enrolled at schools in surrounding Länder (169 observations) 24 The data offer a self-assessed cannabis addiction measure and questions with respect to drug prevalence in school, peer-groups, and life in general.

\section{Identification and Estimation Strategy}

To estimate the effect of an intensified curriculum in affected high schools on youth crime rates, I define the crime rate (CR) of an age group (i) in a Land (s) for a given year (t):

$$
C R_{\text {ist }}=\ln \left(\frac{\text { Records }_{\text {ist }}}{\text { Population }_{\text {ist }}}\right)
$$

The crime rate is the logarithm of the number of offenders divided by the corresponding population of the age group in a Land for a given year. Due to the fact, that the crime data is based on a two-year age group I sum up the share of affected students in groups of two grade levels respectively.

First, I show baseline estimates with a G8 reform dummy following the approach of Chevalier and Marie (2013). The G8 reform dummy indicates when a Gymnasium track of an age cohort was subject to the G8 reform in a given year and Land. In a further step, I regress the crime rates on the actual share of students within the new $G 8$ track to estimate the effect of intensified schooling on crime. The variable G8_share ${ }_{i s t}$ captures the share of students in the 'new high school regime' relative to all adolescents in this age group. I rely on three different specifications to assess the causal impact of the intensified curriculum on crime rates.

\footnotetext{
${ }^{24}$ In general, these students could be used as a control group also because of the later implementation in the surrounding Länder. However, the data do not differentiate between the surrounding Länder of Hamburg.
} 
The basic specification has the following structure:

$$
C R_{i s t}=\beta G 8 \_ \text {share }_{i s t}+\sum_{i} \gamma_{i} \text { Age }_{i}+\sum_{t} \mu_{t} Y_{\text {ear }}+\sum_{s} \alpha_{s} D_{s}+\epsilon_{i s t}
$$

The variables $A g e_{i}$ account for the fixed effects of each age group, Year $r_{t}$ absorbs all year-specific effects, and $D_{s}$ captures Länder fixed effects.

Specification 2 adds control variables captured by the matrix $X_{s t}$ :

$$
C R_{i s t}=\beta G 8 \_ \text {share }_{i s t}+\sum_{i} \gamma_{i} A_{g e}+\sum_{t} \mu_{t} Y e a r_{t}+\sum_{s} \alpha_{s} D_{s}+\varphi X_{s t}+\epsilon_{i s t}
$$

The additional control variables account for the Land's level of police expenditures, the youth unemployment rates for people under the age of 25 , and the overall unemployment rates for each year in each Land. Specification 3 adds Land-specific time trends in linear and quadratic forms, $\sum \sum T_{t} D_{s}$ and $\sum \sum T_{t}^{2} D_{s}$ :

$$
\begin{aligned}
C R_{i s t}=\beta G 8 \_ \text {share }_{i s t}+\sum_{i} \gamma_{i} \text { Age }_{i}+\sum_{t} & \mu_{t} \text { Year }_{t}+\sum_{s} \alpha_{s} D_{s}+\varphi X_{s t} \\
& +\sum_{s} \sum_{t} \delta_{s} T_{t} D_{s}+\sum_{s} \sum_{t} \lambda_{s} T_{t}^{2} D_{s}+\epsilon_{i s t}
\end{aligned}
$$

The staggered implementation of the $G 8$ reform allows for an identification of the reform's impact on crime via (1) differences over time, (2) within Länder, and (3) in the age groups' proportion of students affected by the $G 8$ reform. I use this variation to apply a difference-in-difference approach and assess the causal impact of lengthening the school day on crime outcomes. The sample population comprises of students between the ages of 10 and 22 from all Länder between the school years 1998/99 and 2012/13.

All results of the estimates with the $G 8$ reform dummy and the actual G8-reformed share of students can be interpreted as semi-elasticities, based on a marginal increase of students in the reformed $G 8$ track: a one percentage point increase of affected students in the $G 8$ track triggers a $\beta$ increase in the specific crime rate. The standard errors are clustered on the Land level 25

In the evaluation of the student drug survey, I estimate the effect of the $G 8$ reform on several drug-related binary outcomes using linear probability models. The $G 8$ reform dummy is equal to 1 for all Gymnasium students after the $G 8$ reform and 0 for pre-reform

\footnotetext{
${ }^{25}$ In the case of a Land and cohorts interaction as the cluster unit, regression results deliver smaller standard errors than just the Land as a cluster unit. Therefore, I use only the Land level as a cluster unit to rely on the more conservative estimates. For further information, see Section 5.2 for a discussion of the standard errors.
} 
(G9) Gymnasium students and students from other school tracks.

\section{Results}

\section{$5.1 \quad$ Crime}

We now turn to the econometric analysis of crime data and start with treatment of the G8 reform dummy as a baseline estimation. The underlying sample for this analysis comprises the population aged 10 to 22 years in all 16 Länder between 1998 and 2012. Table 2 includes the regression results from the estimations with a $G 8$ reform dummy that assumes the full age cohort is affected by the $G 8$ reform. Panel (A) of Table 2 presents the $G 8$ reform impact on the total crime rate. Specification (1) includes Land-, year, and age group-fixed effects; specification (2) adds police expenditure and the overall(youth-) unemployment rate; specification (3) adds linear and quadratic Land time trends. Specification (1) shows a small negative effect of -0.05 with the $G 8$ reform dummy, which is statistically significant at the $10 \%$ level. Specification (2) does not show a statistically significant estimate. However, in specification (3) with the full set of control variables, one sees a point estimate of -0.06 , which is statistically significant at the $5 \%$ level. This estimate suggests that the overall crime rate would decrease by $6 \%$ if the full age cohort were affected by the $G 8$ reform.

Panel (B) includes the regression results for drug-related crimes. All specifications (1)-(3) show a statistically negative effect of the $G 8$ reform on drug-related crimes. Specification (1) estimates a decrease of -0.20 due to the $G 8$ reform, which is statistically significant at the $5 \%$ level. Specification (2) shows a slightly larger drop by -0.24 , with statistical significance at the $1 \%$ level. Specification (3) shows a slightly smaller point estimate of -0.14 , but is still statistically significant at the $5 \%$ level. The effect on the violent crime rate is shown in Panel (C). Again, one sees a decreasing influence of the G8 reform on the violent crime rate. Specifications (1) and (3) have virtually the same point estimate at -0.09 , and are statistically significant at the $10 \%$ level. Specification (2) fails to estimate a statistically significant effect, but shows the same negative relation as specifications (1) and (3). Panel (D) includes the G8 reform impact on the property crime rate. The point estimates are not statistically significant and are close to zero, which suggests no effect of the $G 8$ reform on property crimes.

To further analyze the negative effect on drug-related and violent crimes, we turn now to the $G 8$ reform impact measured with the student's share in the reformed $G 8$ track 
Table 2: Reform dummy impact on different crime rates

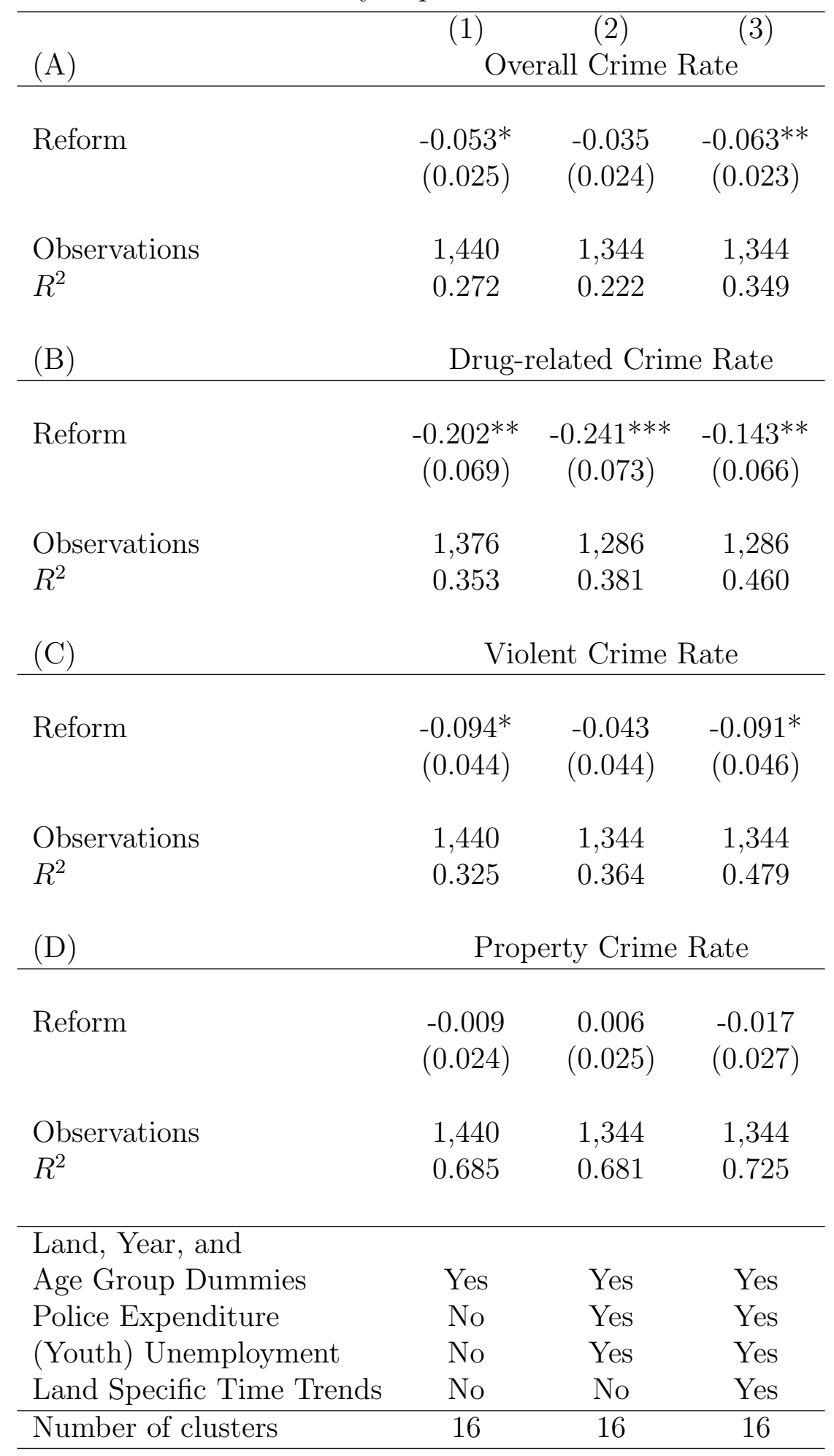

Notes: Based on PKS and administrative student data with the age groups from 10 to 22. Observation period 1998 - 2012 for specification 1 and 1998 - 2011 for specification 2 and 3. Panel B looses observation due to zero incidences of drug-related crimes in some Länder for a few age groups in certain years. All specifications control for the absolute population in a given age group. Standard errors are clustered on the Land level and reported in parenthesis. ${ }^{* * *} \mathrm{p}<0.01,{ }^{* *} \mathrm{p}<0.05,{ }^{*} \mathrm{p}<0.1$ 
(Share in G8 track) on student crime rates. The independent variable in Table 3 captures the percentage of affected students within one age group. Panel (A) of Table 3 presents the effect on the overall crime rate. Specification (1) and the strictest specification (3) estimate a decrease in the overall crime rate of -0.14 (statistically significant at the $5 \%$ and $10 \%$ levels, respectively) due to the reform affected $G 8$ students. One can interpret the effect as follows: for each additional percentage point of affected students, the overall crime rate declines by $0.14 \%$. The estimate from specification (2), with fixed effects and controls for police expenditures, unemployment rates, and youth unemployment rates, diminishes to -0.08 and loses statistical significance.

In the next step, I analyze the $G 8$ reform's impact on different types of crime rates. Table 3 reports in Panel (B) the effect of the $G 8$ reform on drug-related crimes. Again, specification (1), which is controlling for Land, age, and year fixed effects, indicates a drop in drug-related crimes of -0.62 due to the $G 8$ reform. This effect is statistically significant at the $1 \%$ level. The effect in specification (2) even increases to -0.78 (still statistically significant at the $1 \%$ level) when Land-specific control variables are included. Specification (3), with additional Land-specific time trends, again shows an estimate of -0.59 (statistically significant at the $1 \%$ level). This is a huge effect with respect to the magnitude. Given that, on average, one-third of a student's age group attends a Gymnasium, the G8 reform reduces the drug-related crimes by $20 \%$. With respect to the absolute drop in the drug-related crime rate, this $20 \%$ decrease relates to a 0.11 percentage points reduction relative to the average drug-related crime rate of 0.55 percentage points.

Panel (C) of Table 3 shows regression results from the share of $G 8$ track students and violent crimes. All specifications (1)-(3) show a negative sign in the range of -0.22 to -0.36 and are statistically significant. Specification (1) shows the highest negative impact of -0.36 and is statistically significant at the $1 \%$ level. Specification (2), with further control variables, estimates a slightly lower effect of -0.22 , which is only statistically significant at the $10 \%$ level. Specification (3), with the full set of control variables and time trends, shows a higher point estimate of -0.33 and is again statistically significant at the $1 \%$ level. The effect on violent crime in this estimation confirms the negative relationship, which was estimated before with the simple treatment dummy. Panel (D) of Table 3 reports the estimated effect of the $G 8$ reform on property crimes. The point estimates over all specifications are positive; however, none of the estimates are statistically significant due to large standard errors. 
Table 3: G8 reform impact on different crime rates

\begin{tabular}{|c|c|c|c|}
\hline \multirow[b]{2}{*}{ (A) } & (1) & $(2)$ & $(3)$ \\
\hline & \multicolumn{3}{|c|}{ Overall Crime Rate } \\
\hline Share in & $-0.135^{* *}$ & -0.078 & $-0.135^{*}$ \\
\hline G8 Track & $(0.061)$ & $(0.066)$ & $(0.077)$ \\
\hline Observations & 1,440 & 1,344 & 1,344 \\
\hline$R^{2}$ & 0.274 & 0.221 & 0.345 \\
\hline (B) & \multicolumn{3}{|c|}{ Drug-related Crime Rate } \\
\hline Share in & $-0.617^{* * *}$ & $-0.778^{* * *}$ & $-0.585^{* * *}$ \\
\hline G8 Track & $(0.177)$ & $(0.197)$ & $(0.135)$ \\
\hline Observations & 1,376 & 1,286 & 1,286 \\
\hline$R^{2}$ & 0.355 & 0.387 & 0.467 \\
\hline (C) & \multicolumn{3}{|c|}{ Violent Crime Rate } \\
\hline Share in & $-0.362^{* * *}$ & $-0.216^{*}$ & $-0.333^{* * *}$ \\
\hline G8 Track & $(0.099)$ & $(0.102)$ & $(0.101)$ \\
\hline Observations & 1,440 & 1,344 & 1,344 \\
\hline$R^{2}$ & 0.340 & 0.372 & 0.487 \\
\hline (D) & \multicolumn{3}{|c|}{ Property Crime Rate } \\
\hline Share in & 0.018 & 0.074 & 0.038 \\
\hline G8 Track & $(0.063)$ & $(0.071)$ & $(0.086)$ \\
\hline Observations & 1,440 & 1,344 & 1,344 \\
\hline$R^{2}$ & 0.685 & 0.682 & 0.725 \\
\hline \multicolumn{4}{|l|}{ Land, Year, and } \\
\hline Age Group Dummies & Yes & Yes & Yes \\
\hline Police Expenditure & No & Yes & Yes \\
\hline (Youth) Unemployment & No & Yes & Yes \\
\hline Land Specific Time Trends & No & No & Yes \\
\hline Number of clusters & 16 & 16 & 16 \\
\hline
\end{tabular}

Notes: Based on PKS and administrative student data with the age groups from 10 to 22. Observation period 1998 - 2012 for specification 1 and 1998 - 2011 for specification 2 and 3. Panel B looses observation due to zero incidences of drug-related crimes in some Länder for a few age groups in certain years. All specifications control for the absolute population in a given age group. Standard errors are clustered on the Land level and reported in parenthesis. ${ }^{* * *} \mathrm{p}<0.01,{ }^{* *} \mathrm{p}<0.05,{ }^{*} \mathrm{p}<0.1$ 
Table 4: Age group specific G8 reform impact on drug-related crimes

(1) (2) (3)

Drug-related Crime Rate

\begin{tabular}{lccc} 
Share in G8 & $-2.343^{* *}$ & $-1.903^{*}$ & -1.283 \\
at Age 10-11 & $(0.969)$ & $(1.046)$ & $(1.001)$ \\
\hline Share in G8 & $-0.907^{* * *}$ & $-1.032^{* * *}$ & $-0.807^{* * *}$ \\
at Age 12-13 & $(0.286)$ & $(0.298)$ & $(0.270)$ \\
\hline Share in G8 & $-0.406^{* *}$ & $-0.592^{* * *}$ & $-0.460^{* * *}$ \\
at Age 14-15 & $(0.167)$ & $(0.191)$ & $(0.139)$ \\
\hline Share in G8 & -0.319 & $-0.469^{*}$ & $-0.365^{*}$ \\
at Age 16-17 & $(0.206)$ & $(0.227)$ & $(0.190)$ \\
\hline Share in G8 & -0.252 & -0.372 & -0.281 \\
at Age 18-20 & $(0.719)$ & $(0.922)$ & $(0.791)$
\end{tabular}

\begin{tabular}{lccc}
\hline Land, Year, and & & & \\
Age Group Dummies & Yes & Yes & Yes \\
Police Expenditure & No & Yes & Yes \\
(Youth) Unemployment & No & Yes & Yes \\
Land Specific Time Trends & No & No & Yes \\
\hline Observations & 1,376 & 1,286 & 1,286 \\
$R^{2}$ & 0.3751 & 0.3969 & 0.4720 \\
Number of clusters & 16 & 16 & 16 \\
\hline
\end{tabular}

Notes: Based on PKS and administrative student data with the age groups from 10 to 22 . Observation period 1998 - 2012 for specification 1 and 1998 - 2011 for specification 2 and 3. All specifications control for the absolute population in a given age group. Standard errors are clustered on the Land level and reported in parenthesis. ${ }^{* * *} \mathrm{p}<0.01,{ }^{* *} \mathrm{p}<0.05, * \mathrm{p}<0.1$

An analysis of different effects of the affected age groups with respect to drug-related crimes is shown in Table 4. The table includes effects from one single regression with a set of variables capturing the share of students in the $G 8$ track of each age group. The biggest effect is present for the youngest age group (10-11) in specification (1) with a point estimate of -2.34 , which is statistically significant at the $5 \%$ level. However, the effect diminishes slightly in specifications (2) and (3) and is no longer statistically significant in the strictest specification (3). Robust estimates with respect to the different specifications are present for the age groups (12-13) and (14-15), which indicates an almost twice as high effect for the younger group (12-13). The effect of this group (12-13) varies between -0.81 and -1.03 and is statistically significant at the $1 \%$ level. The slightly older age group (14-15) shows a drop from -0.41 to -0.59 , with higher negative effects in specifications (2) and (3). Whereas the effect in specification (1) is statistically significant at the $5 \%$ level, specifications (2) and (3) show a statistical significance of the effect at the 
1\% level. The point estimates of the older age group (16-17) are negative too; however, only specifications (2) and (3) yield a statistically significant effect at the $10 \%$ level for the age group (16-17). Furthermore, the effect of the share of G8-reformed students is not statistically significant for the oldest age group (18-20). One must bear in mind that only the 18-year-old students in this age group were subject to the $G 8$ reform and only for a half-calendar year ${ }^{26}$ As described before, an increase in grade repetition could bias the results of these age groups (16-17 and 18-20) and one should treat these results with caution.

Table 5: G8 reform impact on cannabis dealing and consuming rate

\begin{tabular}{|c|c|c|c|}
\hline \multirow[b]{2}{*}{$(\mathrm{A})$} & $(1)$ & $(2)$ & $(3)$ \\
\hline & \multicolumn{3}{|c|}{ Cannabis Dealing Crime Rate } \\
\hline Share in & -0.067 & -0.248 & -0.238 \\
\hline G8 Track & $(0.260)$ & $(0.294)$ & $(0.268)$ \\
\hline Observations & 1,218 & 1,138 & 1,138 \\
\hline$R^{2}$ & 0.323 & 0.337 & 0.475 \\
\hline$(\mathrm{B})$ & \multicolumn{3}{|c|}{ Cannabis Consuming Crime Rate } \\
\hline Share in & $-0.602^{* * *}$ & $-0.812^{* * *}$ & $-0.719 * * *$ \\
\hline G8 Track & $(0.172)$ & $(0.199)$ & $(0.172)$ \\
\hline Observations & 1,350 & 1,263 & 1,263 \\
\hline$R^{2}$ & 0.340 & 0.367 & 0.442 \\
\hline \multicolumn{4}{|l|}{ Land, Year, and } \\
\hline Age Group Dummies & Yes & Yes & Yes \\
\hline Police Expenditure & No & Yes & Yes \\
\hline (Youth) Unemployment & No & Yes & Yes \\
\hline Land Specific Time Trends & No & No & Yes \\
\hline Number of clusters & 16 & 16 & 16 \\
\hline
\end{tabular}

Notes: Based on PKS and administrative student data with the age groups from 10 to 22. Observation period 1998 - 2012 for specification 1 and 1998 - 2011 for specification 2 and 3 . Panel A looses observation due to zero incidences of crimes related to dealing with cannabis in some Länder for a few age groups in certain years. All specifications control for the absolute population in a given age group. Standard errors are clustered on the Land level and reported in parenthesis. ${ }^{* * *} \mathrm{p}<0.01,{ }^{*} \mathrm{p}<0.05,{ }^{*} \mathrm{p}<0.1$

Table 5 focuses solely on the $G 8$ reform's impact on cannabis, which is the most prominent illegal drug in Germany and accounts for more than half of all drug-related crimes. One can expect that the $G 8$ reform has diverse results when discriminating between the serious crime of dealing and the rather delinquent behavior of the pure consumption of

\footnotetext{
${ }^{26}$ Since the German school year usually ends in June or July, the overlap of the student enrollment data and yearly crime data (based on the calendar year) is reduced to one-half.
} 
cannabis. Therefore, Table 5 separates between the G8 reform impact on the rate of dealing with cannabis and the rate of consuming cannabis. Panel (A) of Table 5 shows the effect from the relative students intake in the $G 8$ track effect on the cannabis dealing rate. The $G 8$ reform seemed not to have an effect on the actual rate of dealers. Panel (B) of Table 5 presents the effect on the cannabis use rate. The negative point estimates of specifications (1)-(3) range from -0.60 to -0.81 and are all statistically significant at the $1 \%$ level, suggesting a strong negative effect of the $G 8$ reform on the cannabis consumption of a student's age group.

\subsection{Sensitivity Analysis}

The fact that the share of other school types has varied over recent years, as the share of students in Gymnasium has increased, makes it possible that newer trends in the school type composition are correlated with the $G 8$ reform. Therefore, I estimate the effects from G8-reformed students on drug-related crimes while controlling for other shares of school types. The share of other school types (Hauptschule, Realschule, and comprehensive schools) or the share of the non-reformed $G 9$ track do not drive the estimates of the $G 8$ reformed students. Estimations with the share of $G 8$ and $G 9$ track students occasionally deliver a higher level of statistical significance for the effect of the share in the $G 8$ track; however, the point estimates of the students in the G9 track are closer to zero and never statistically significant.

All estimation results from the share of students in the $G 8$ track and the police crime data show the same level of significance when the standard errors are clustered on the interaction between Land and cohorts. Due to lower standard errors of this and other cluster units, the presented results with the Land as cluster delivers the most conservative results (largest standard errors) as suggested by Bertrand et al.(2004). The fact, that the Land and cohort cluster units deliver larger standard errors suggests that serial correlation seems to be not present in the underlying panel data.

However, the problem of too few clusters due to only sixteen German Länder might generate over-rejection resulting in too narrow confidence intervals as discussed in Cameron and Miller (2015). Therefore, I perform all regression results as a robustness check with a wild bootstrap procedure. The estimations confirm the significance of the results derived from regressions with the police crime statistics and student drug survey and do not deliver wider/broader confidence intervals. Regression results with only the G8 reform- 
affected sample [without the unaffected age group (21-22)], do not change the estimates of the $G 8$ reform effect on the crime behavior of younger $G 8$-affected students.

To estimate if a 'catch-up' effect takes place in the years after the graduation of G8 reform-affected students, I estimate a model where another treatment dummy indicates former G8 track students. This treatment dummy follows students who attended the G8-reformed Gymnasium after their school career is finished and they potentially pursue a tertiary education or an apprenticeship. This after school reform dummy follows G8 reform-affected age cohorts after graduation from the Gymnasium, when they are between 19- and 22-years-old. One could expect to see an effect if former $G 8$ track students use the time after graduation to engage in criminal activity, because the time and commitment constraints of G8-reformed Gymnasium prevented them from doing so earlier. However, given that not all Länder finished so far the $G 8$ reform implementation and others just released their first double graduation cohorts, these results should be treated with caution due to a low number of former $G 8$-affected students. With respect to drug-related crimes, it appears that no catch-up effect occurs. Occasionally, the negative impact of former $G 8$ track students on drug-related crimes seems to be prolonged after high school graduation; however, the effect is not robust over all specifications. The negative effect of the G8 reform on violent crimes could face a catch-up effect after high school graduation. The impact of former $G 8$ track students with the after school reform dummy on violent crimes is positive and comparable with the negative violent crime effect of the share of $G 8$ track students with respect to the magnitude ${ }^{27}$

To address the potential problem of grade repetition as discussed by Huebener and Marcus (2015), I estimate all regression results from the crime data with an additional control for the share of grade repetition, which was affected at least partially by the reform. I use one variable for the grade repetition of Gymnasium students and another variable for all other school types. These variables control for the lagged (previous year) grade repetition rate of the school types in the next higher grade level. These control variables take into account that grade repeating students show up in the crime data in the next higher age cohort even when they remain in the grade level from the previous year. These regression results suggest that the presented G8-reform effect on crime is not driven by the increased grade repetition of reform-affected students ${ }^{28}$

\footnotetext{
${ }^{27}$ These regression results are reported in Table 10 in the Appendix.

${ }^{28}$ Results are available from the author upon request.
} 


\subsection{Survey Data}

We turn now to the impact of the $G 8$ reform on the student drug survey to provide further evidence of reduced drug-consumption. To ensure that the effect was mainly driven by the affected students in the high school track and not by changes in the drug consumption of students in other school tracks, I use a student drug survey. Potentially, one could think that the effect from the G8-reformed students exerts an additional effect on the peer group of $G 8$-students if the peer group is distributed across different school types.

The sample consists of a repeated cross-section and covers students from reformed as well as non-reformed schools of different types. The G8 reform took place within the third wave of the survey and affected all Gymnasium students in the last two waves. The Schulbus survey data from the Land of Hamburg is evaluated using a linear probability model that assigns all Gymnasium students after the $G 8$ reform with a reform dummy.

Table 6 shows the impact of the $G 8$ reform on cannabis consumption within the school environment. The definition of school environment includes the school grounds and external school trips. The first three columns capture the estimates of the full-sample and columns four to six restrict the sample to students younger than sixteen years. This assures that the sample is not driven by sample selection of school dropouts and early starters in the job market. Furthermore, this age group faced the biggest increase of 'shifted' school hours. The negative relation of the G8 reform on the consumption of cannabis within the school environment is statistically significant in the specification without controls [(1) and (4)] and some control variables [(2) and (5)] for the full and age-restricted samples, respectively. Although the relation is not significant, it is negative in specifications (3) and (6), which both include the full set of control variables.

If this effect were positive, then the drop in the police crime statistics could be explained by a shift of crime to the school environment due to the longer school hours. This could be the case if delinquencies within the school environment are more likely to be sanctioned by teachers rather than the police to reduce administrative duties or to preserve the school's reputation. Furthermore, police patrols, which are less prevalent in schoolyards than outside the school environment, could result in fewer crimes being detected by the police. The evidence clearly rejects that the consumption of cannabis was

shifted into the school environment. In fact the (insignificant) negative point estimates indicate that cannabis consumption within the school decreased slightly as instructional hours increased. 
Table 6: G8 reform impact on cannabis using in school within the last year

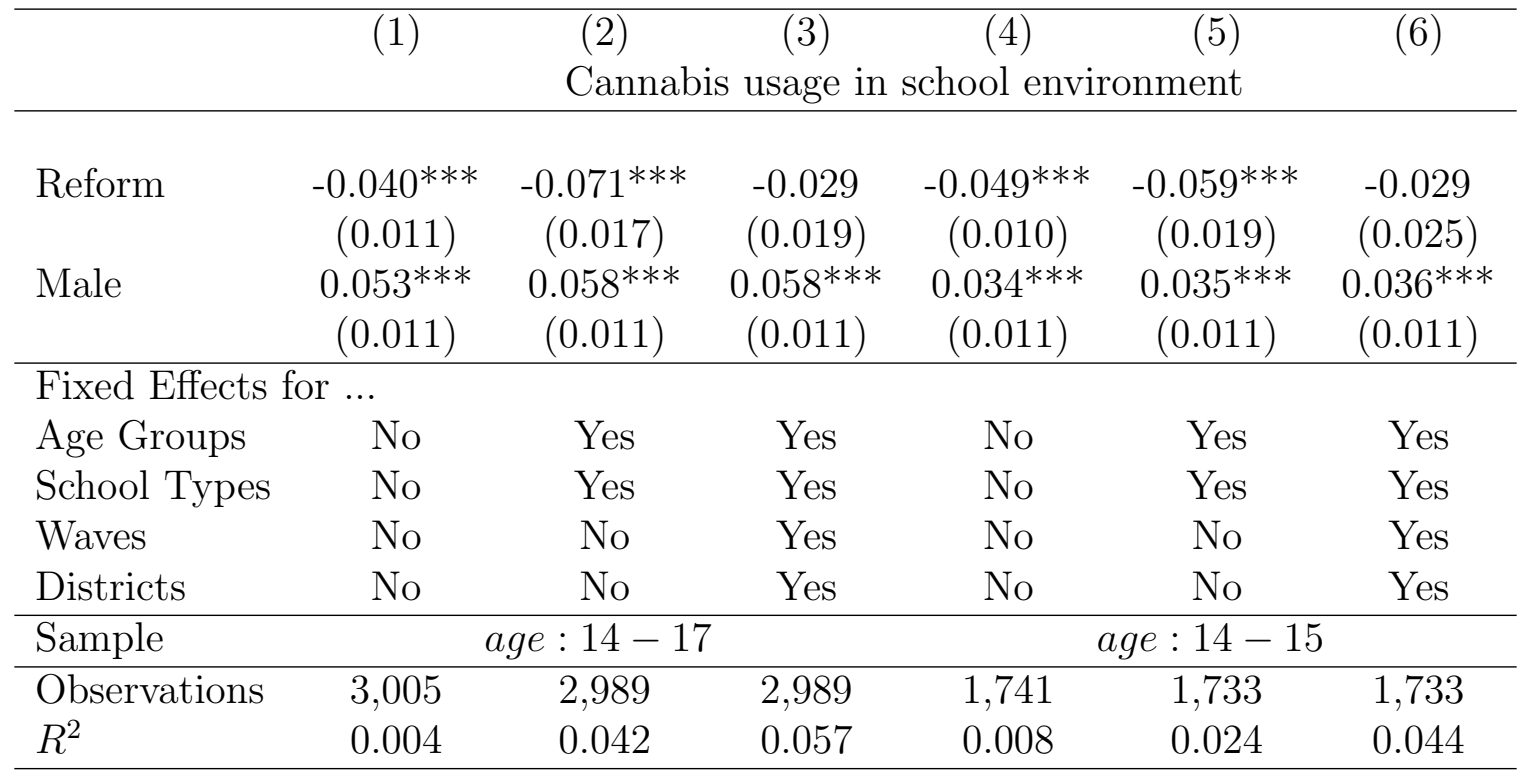

Notes: Based on weighted survey data from Schulbus waves. Observation period 2004 - 2012. Cannabis in school is a dummy variable equal to one if at least once cannabis was consumed in the school environment within the last 12 months, zero otherwise. The definition of school environment includes, among others, (breaks at) the schoolyard and school excursions. Robust standard errors are reported in parenthesis. *** $\mathrm{p}<0.01, * * \mathrm{p}<0.05, * \mathrm{p}<0.1$.

Table 7: G8 reform impact on cannabis addiction

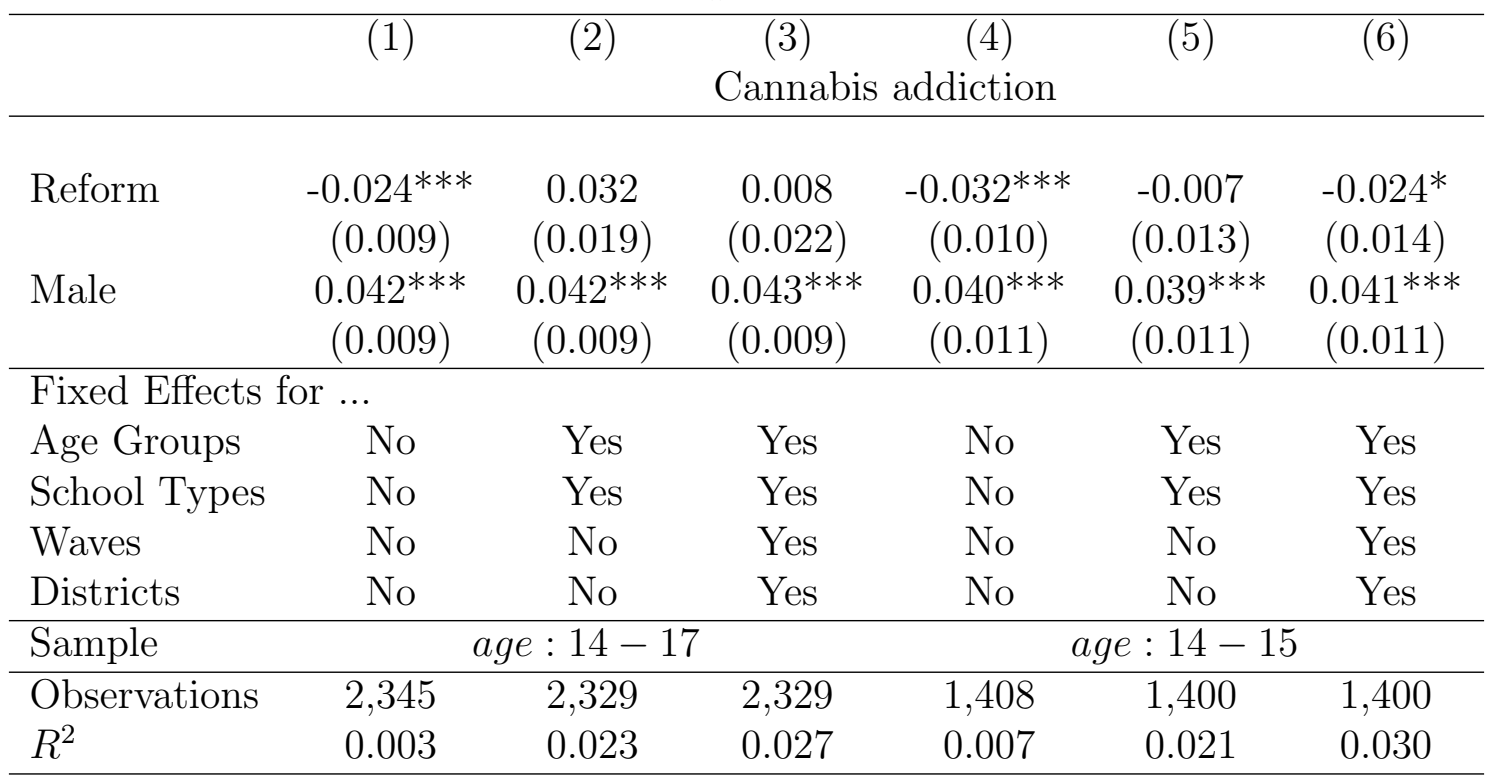

Notes: Based on weighted survey data from Schulbus waves. Observation period 2004 - 2012. Cannabis addiction is observed if at least 2 items of the Severity of Dependence Scale apply. Robust standard errors are reported in parenthesis. $* * * \mathrm{p}<0.01,{ }^{*} \mathrm{p}<0.05,{ }^{*} \mathrm{p}<0.1$. 
The reducing effect of the $G 8$ reform on drug consumption that I identified in the crime statistics is also present in the student drug survey. Table 7 shows the regression results for an indicator of cannabis addiction as a dependent variable. ${ }^{29}$

For the full sample, only the first specification (with only a male dummy indicator) shows a statistically negative relationship. For the sample restriction to the age group (14-15), specifications (4)-(6) indicate a negative sign that ranges from -0.01 to -0.03 . Specification (6), with the full set of control variables, suggests that the rate of cannabisaddicted students decreased by $-0.02 \%$ for 14 - to 15 -year-old students after introduction of the $G 8$ reform 30

Table 8 shows the effect on the cannabis prevalence within the peer groups of G8reformed students. The outcome variable is a dummy equal to one whenever the student indicates that half or more of their peer group has experiences with cannabis. Again, one finds that the $G 8$ reform goes in line with a decreasing prevalence of cannabis within the peer group. Although the specifications (1) and (4) as well as (2) and (5) show a highly statistically significant relation, significance vanishes in the most strict specifications (3) and (6).

Table 9 shows the $G 8$ reform impact on the monthly prevalence of cannabis consumption in the top panel and the lifetime prevalence in the bottom panel. The negative and statistically significant pattern of estimates from the less strict specifications is also present here. The fact that the point estimates for the lifetime prevalence is more than twice as high could explain that the $G 8$ reform impact is more likely to have an effect on the extensive margin and less on the intensive margin. In other words, the $G 8$ reform seemed to have stopped students from starting to use cannabis or delayed the starting age rather than making them just consume less.

\footnotetext{
${ }^{29}$ Cannabis addiction is measured with a binary variable that is equal to one if at least two out of five items of cannabis addiction symptoms apply. The 5 symptoms are measured on the Severity of Dependence Scale and defined in the Appendix.

${ }^{30}$ The results are robust when only the sub-sample of males is considered for the regression.
} 
Table 8: G8 reform impact on cannabis prevalence in peer-group
(1)
(2)
(3)
(4)
$(5)$
(6)

Cannabis prevalence in peer-group

\begin{tabular}{lcccccc}
\hline Reform & $-0.088^{* * *}$ & $-0.061^{* * *}$ & -0.014 & $-0.126^{* * *}$ & $-0.079^{* * *}$ & -0.032 \\
\multicolumn{1}{l}{ Male } & $(0.015)$ & $(0.020)$ & $(0.029)$ & $(0.016)$ & $(0.027)$ & $(0.040)$ \\
& $0.047^{* * *}$ & $0.047^{* * *}$ & $0.046^{* * *}$ & $0.042^{* *}$ & $0.039^{* *}$ & $0.036^{* *}$ \\
& $(0.015)$ & $(0.014)$ & $(0.014)$ & $(0.017)$ & $(0.017)$ & $(0.017)$ \\
\hline Fixed Effects for $\ldots$ & & & & & \\
Age Groups & No & Yes & Yes & No & Yes & Yes \\
School Types & No & Yes & Yes & No & Yes & Yes \\
Waves & No & No & Yes & No & No & Yes \\
Districts & No & No & Yes & No & No & Yes \\
\hline Sample & \multicolumn{7}{c}{$a g e: 14-17$} & & & age $: 14-15$ & \\
\hline Observations & 3,652 & 3,636 & 3,636 & 2,094 & 2,086 & 2,086 \\
$R^{2}$ & 0.009 & 0.056 & 0.076 & 0.021 & 0.056 & 0.066 \\
\hline
\end{tabular}

Notes: Based on weighted survey data from Schulbus waves. Observation period 2004 - 2012. Cannabis prevalence in peer-group is a dummy variable equal to one if at least half of the peer-group is consuming cannabis, zero otherwise. Robust standard errors are reported in parenthesis. $* * * \mathrm{p}<0.01, * * \mathrm{p}<0.05, *$ $\mathrm{p}<0.1$.

Table 9: 68 reform impact on cannabis prevalence
(1)
(2)
(3)
(4)
(5)
(6)

Cannabis 30-day prevalence

\begin{tabular}{lcccccc} 
Reform & $-0.020^{*}$ & -0.005 & 0.017 & $-0.038^{* * *}$ & -0.017 & 0.003 \\
Male & $(0.012)$ & $(0.016)$ & $(0.023)$ & $(0.013)$ & $(0.021)$ & $(0.030)$ \\
& $0.074^{* * *}$ & $0.075^{* * *}$ & $0.074^{* * *}$ & $0.067^{* * *}$ & $0.065^{* * *}$ & $0.064^{* * *}$ \\
& $(0.011)$ & $(0.011)$ & $(0.011)$ & $(0.013)$ & $(0.013)$ & $(0.013)$ \\
\hline Observations & 3,847 & 3,831 & 3,831 & 2,219 & 2,211 & 2,211 \\
$R^{2}$ & 0.001 & 0.033 & 0.040 & 0.004 & 0.028 & 0.036 \\
\hline
\end{tabular}

Cannabis lifetime prevalence

\begin{tabular}{lcccccc} 
Reform & $-0.066^{* * *}$ & $-0.066^{* * *}$ & 0.047 & $-0.104^{* * *}$ & $-0.105^{* * *}$ & 0.035 \\
Male & $(0.016)$ & $(0.022)$ & $(0.033)$ & $(0.017)$ & $(0.030)$ & $(0.043)$ \\
& $0.104^{* * *}$ & $0.109^{* * *}$ & $0.108^{* * *}$ & $0.079^{* * *}$ & $0.080^{* * *}$ & $0.080^{* * *}$ \\
& $(0.015)$ & $(0.015)$ & $(0.015)$ & $(0.018)$ & $(0.018)$ & $(0.017)$ \\
\hline Observations & 3,849 & 3,833 & 3,833 & 2,221 & 2,213 & 2,213 \\
$R^{2}$ & 0.005 & 0.062 & 0.081 & 0.013 & 0.041 & 0.059 \\
\hline Fixed Effects for & $\ldots$ & & & & & \\
Age Groups & No & Yes & Yes & No & Yes & Yes \\
School Types & No & Yes & Yes & No & Yes & Yes \\
Waves & No & No & Yes & No & No & Yes \\
Districts & No & No & Yes & No & No & Yes \\
\hline \multicolumn{7}{l}{ Sample } \\
\hline
\end{tabular}

Notes: Based on Schulbus. Observation period 2004 - 2012. Robust standard errors are reported in parenthesis. *** $\mathrm{p}<0.01,{ }^{* *} \mathrm{p}<0.05,{ }^{*} \mathrm{p}<0.1$ 


\section{Conclusion}

This analysis leads to the conclusion that the moderate decline in the overall crime rate is due to the stronger decline in drug-related and violent crimes. However, this reduction can be mainly explained by a drop in delinquencies of the cannabis-user rate rather than the use of hard drugs or even drug dealers. Furthermore, the analysis provides evidence that lengthening the school day at lower grades, when students are aged 12 to 15 years, reduces drug-related crimes (at least for the high school track). The drop in drug-related crimes is mainly attributable to cannabis possession and no effect on the cannabis dealing rate is present. Further survey evidence clearly links the decrease in cannabis consumption to G8-affected students and rejects the hypothesis of drug consumption shifted into school hours. In fact, the survey evidence even suggests that cannabis consumption within the school decreases due to increased instructional hours. Furthermore, the prevalence of cannabis within the peer group decreases after the reform. The analysis of the student survey results indicate that the G8 reform has stopped students from using cannabis or at least has delayed the starting age rather than just reducing the consumption.

A direct analysis of the eliminated school year (old grade 13) on crime is not feasible because this age (grade) level cannot be carefully identified within the underlying crime data. In general, I cannot rule out that the decreased crime measures during school time rise during the eliminated school year, which is the first year after graduation. However, the first cohorts of graduates who went through the new $G 8$ reform system do not show a tendency to catch-up with their drug consumption in the first years after their school career. A catch-up effect of violent crime seems to be present for these cohorts. Further analysis is necessary to identify the direct effect of the eliminated school year. 


\section{References}

Anderson, D. Mark (2014), 'In school and out of trouble? The minimum dropout age and juvenile crime', Review of Economics and Statistics, Vol. 96(2), p. 318-331.

Anderson, D. Mark, and Mary Beth Walker (2015), 'Does shortening the school week impact student performance? Evidence from the four-day school week', Education Finance and Policy, Vol. 10(3), p. 314-349.

Åslund, Olof, Hans Grönqvist, Caroline Hall, and Jonas Vlachos (2015), 'Education and criminal behavior: Insights from an expansion of upper secondary school', IZA Discussion Paper, 9374.

Baumgärtner, Theo, and Johannes Kestler (2014), 'Suchtmittelgebrauch, Computerspielverhalten, Internetnutzung und Glücksspielerfahrungen von Jugendlichen in Hamburg und drei Modellregionen in Deutschland. Deskriptive Ergebnisse der SCHULBUS-regionalStudie 2012', HLS/BfS-Berichte, SB 14-B1.

Becker, Gary S. (1968), 'Crime and punishment: An economic approach', Journal of Political Economy, Vol. 76(2), p. 169-217.

Berthelon, Matias E., and Diana I. Kruger (2011), 'Risky behavior among youth: Incapacitation effects of school on adolescent motherhood and crime in Chile', Journal of Public Economics, Vol. 95(1), p. 41-53.

Bertrand, Marianne, Esther Duflo, and Sendhil Mullainathan (2004), 'How much should we trust Differences-in-Differences estimates?', Quarterly Journal of Economics, Vol. 119(1), p. 249-275.

Brilli, Ylenia, and Marco Tonello (2015), 'Rethinking the crime reducing effect of education? Mechanisms and evidence from regional divides', Bank of Italy, Economic Research and International Relations Area, 1008.

Büttner, Bettina, and Stephan L. Thomsen (2015), 'Are we spending too many years in school? Causal evidence of the impact of shortening secondary school duration', German Economic Review, Vol. 16(1), p. 65-86.

Cameron, A. Colin, and Douglas L. Miller (2015), 'A practitioner's guide to cluster-robust inference', Journal of Human Resources, Vol. 50(2), p. 317-372.

Chevalier, Arnaud, and Olivier Marie (2013), 'Economic uncertainty, parental selection, and the criminal activity of the 'children of the wall' ', CESifo Working Paper, 4462. 
Chevalier, Arnaud, and Olivier Marie (2016), 'Economic uncertainty, parental selection, and children's educational outcomes', Journal of Political Economy, forthcoming.

Dahmann, Sarah, and Silke Anger (2014), 'The impact of education on personality: Evidence from a German high school reform', IZA Discussion Paper, 8139.

Deming, David James (2011), 'Better schools, less crime?', The Quarterly Journal of Economics, Vol. 126, p. 2063-2115.

Drogenbeauftragte der Bundesregierung (2013), 'Drogen-und Suchtbericht', Berlin, Germany: Federal Ministry of Health.

Dustmann, Christian (2004), 'Parental background, secondary school track choice, and wages', Oxford Economic Papers, Vol. 56(2), p. 209-230.

Ehrlich, Isaac (1975), 'On the relation between education and crime', in F. Thomas Juster (Ed.), Education, income, and human behavior (p. 313-337), New York: McGraw-Hill.

Huebener, Mathias, and Jan Marcus (2015), 'Moving up a gear: The impact of compressing instructional time into fewer years of schooling', DIW Discussion Paper, 1450.

Kline, Patrick (2012), 'The impact of juvenile curfew laws on arrests of youth and adults', American Law and Economics Review, Vol. 14(1), p. 44-67.

Kühn, Svenja M., Isabell van Ackeren, Gabriele Bellenberg, Christian Reintjes, and Grit im Brahm (2013),'Wie viele Schuljahre bis zum Abitur? Eine multiperspektivische Standortbestimmung im Kontext der aktuellen Schulzeitdebatte', Zeitschrift für Erziehungswissenschaften, Vol. 16, p. 115-136.

Lefgren, Lars, and Brian A. Jacob (2003), 'Are idle hands the devil's workshop? Incapacitation, concentration, and juvenile crime', American Economic Review, Vol. 93(5), p. $1560-1577$.

Lochner, Lance, and Enrico Moretti (2004), 'The effect of education on crime: Evidence from prison inmates, arrests, and self-reports', American Economic Review, Vol. 94(1), p. $155-189$.

Luallen, Jeremy (2006), 'School's out... forever: A study of juvenile crime, at-risk youths and teacher strikes', Journal of Urban Economics, Vol. 59(1), p. 75-103.

Machin, Stephen, Olivier Marie, and Sunčica Vujić (2011), 'The crime reducing effect of education', The Economic Journal, Vol. 121(552), p. 463-484.

Meyer, Tobias, Stephan L. Thomsen, and Heidrun Schneider (2015), 'New evidence on 
the effects of the shortened school duration in the German states: An evaluation of postsecondary education decisions', IZA Discussion Papers, 9507.

Milde-Busch, Astrid, A. Blaschek, I. Borggräfe,R. von Kries, A. Straube and F. Heinen (2010), 'Besteht ein Zusammenhang zwischen der verkürzten Gymnasialzeit und Kopfschmerzen und gesundheitlichen Belastungen bei Schülern im Jugendalter?', Klinische Pädiatrie, Vol. 222(04), p. 1-6.

\section{Appendix}

\section{Tables}

Table 10: 68 reform impact on former students' crime rate

\begin{tabular}{|c|c|c|c|}
\hline \multirow[b]{2}{*}{ (A) } & (1) & $(2)$ & $(3)$ \\
\hline & \multicolumn{3}{|c|}{ Drug-related Crime Rate } \\
\hline $\begin{array}{l}\text { G8 dummy } \\
\text { after school }\end{array}$ & $\begin{array}{c}-0.267^{* * *} \\
(0.079)\end{array}$ & $\begin{array}{c}-0.267^{* * *} \\
(0.088)\end{array}$ & $\begin{array}{c}-0.012 \\
(0.082)\end{array}$ \\
\hline $\begin{array}{l}\text { Observations } \\
R^{2}\end{array}$ & $\begin{array}{l}1,376 \\
0.342\end{array}$ & $\begin{array}{l}1,286 \\
0.365\end{array}$ & $\begin{array}{l}1,286 \\
0.456\end{array}$ \\
\hline$(\mathrm{B})$ & \multicolumn{3}{|c|}{ Violent Crime Rate } \\
\hline $\begin{array}{l}\text { G8 dummy } \\
\text { after school }\end{array}$ & $\begin{array}{c}0.131^{* * *} \\
(0.021)\end{array}$ & $\begin{array}{c}0.137^{* * *} \\
(0.023)\end{array}$ & $\begin{array}{c}0.086^{* *} \\
(0.039)\end{array}$ \\
\hline $\begin{array}{l}\text { Observations } \\
R^{2}\end{array}$ & $\begin{array}{l}1,440 \\
0.316\end{array}$ & $\begin{array}{l}1,344 \\
0.368\end{array}$ & $\begin{array}{l}1,344 \\
0.469\end{array}$ \\
\hline $\begin{array}{l}\text { Land, Year, and } \\
\text { Age Group Dummies } \\
\text { Police Expenditure } \\
\text { (Youth) Unemployment } \\
\text { Land Specific Time Trends }\end{array}$ & $\begin{array}{l}\text { Yes } \\
\text { No } \\
\text { No } \\
\text { No }\end{array}$ & $\begin{array}{l}\text { Yes } \\
\text { Yes } \\
\text { Yes } \\
\text { No }\end{array}$ & $\begin{array}{l}\text { Yes } \\
\text { Yes } \\
\text { Yes } \\
\text { Yes }\end{array}$ \\
\hline Number of clusters & 16 & 16 & 16 \\
\hline
\end{tabular}

Notes: Based on PKS and administrative student data with the age groups from 10 to 22. Observation period 1998 - 2012 for specification 1 and 1998 - 2011 for specification 2 and 3. Panel A looses observation due to zero incidences of crimes related to dealing with cannabis in some Länder for a few age groups in certain years. All specifications control for the absolute population in a given age group. Standard errors are clustered on the Land level and reported in parenthesis. ${ }^{* * *} \mathrm{p}<0.01,{ }^{* *} \mathrm{p}<0.05,{ }^{*} \mathrm{p}<0.1$ 


\section{Definition: Severity of Dependence Scale SDS}

1 Did you ever think your use of cannabis was out of control?

2 Did the prospect of missing cannabis make you very anxious or worried?

3 Did you worry about your use of cannabis?

4 Did you wish you could stop your use of cannabis?

5 How difficult would you find it to stop or go without cannabis?

- Responses:

- Item 1-4: never or almost never (0); sometimes(1); often (2); always or nearly always (3)

- Item 5: not difficult (0); quite difficult (1), very difficult (2); impossible (3)

- The code from the responses are added and account for a cannabis addiction if the value is at least 2 according to the definition of the SDS. 